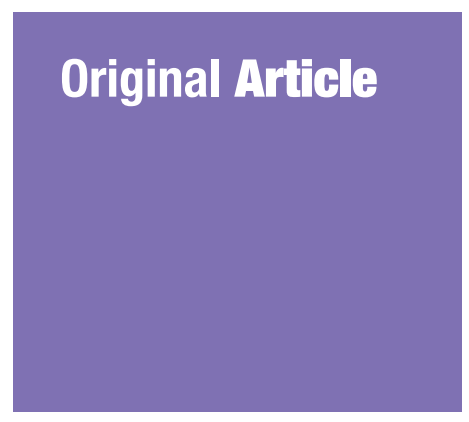

Sulbmitted: 26 Jan 2021

Accepted: 20 Mar 2021

Online: 26 Aug 2021

\section{Characterisation of the Prevailing Multidrug Pseudomonas aeruginosa Strains from Surgical Wound Using 16S rRNA Sequencing Technique}

\section{Eremwanarue Osagie Aibuedefe ${ }^{1,2}$, Nwawuba Stanley Udogadi ${ }^{3}$, SHITtu Olalekan Hakeem ${ }^{1}$}

\author{
1 Department of Plant Biology and Biotechnology, University of Benin, \\ Ugbowo, Benin City, Nigeria \\ 2 Lahor Research Laboratories and Diagnostics Centre, Benin City, Nigeria \\ 3 Centre for Forensic Programmes and DNA Studies, University of Benin, \\ Ugbowo, Benin City, Nigeria
}

To cite this article: Eremwanarue OA, Nwawuba SU, Shittu OH. Characterisation of the prevailing multidrug Pseudomonas aeruginosa strains from surgical wound using 16S rRNA sequencing technique. Malays $J$ Med Sci. 2021;28(4):37-49. https://doi.org/10.21315/mjms2021.28.4.5

To link to this article: https://doi.org/10.21315/mjms2021.28.4.5

\title{
Abstract
}

Background: Pseudomonas aeruginosa ( $P$. aeruginosa) is prevalent in hospital-acquired surgical wound infections. It exhibits both innate and acquired resistance to a broad range of antimicrobials and remains a principal problem in clinical practice.

Methods: In total, 284 sterile surgical wound swabs (142 each) were collected from two government hospitals: Central Hospital Benin (CHB) and University of Benin Teaching Hospital (UBTH) in Benin City, Nigeria. Pseudomonas spp. isolated from both hospitals were screened with eight different antibiotics by way of disk diffusion method. Polymerase chain reaction (PCR) amplification of 34 multiple drug-resistant isolates was carried out using genus-specific primer set on extracted genomic DNA for the identification of Pseudomonas spp. and substituent 16S rRNA sequencing to determine the prevailing strains in the two locations.

Results: Sixty-two Pseudomonas spp. were isolated from the two locations (27 isolates from CHB and 35 isolates from the UBTH). Surgical wound infections screened with regularly used antibiotics revealed that 17 (62.9\%) isolates from CHB and $20(57.1 \%)$ isolates from UBTH were multiple drug resistant Pseudomonas spp. PCR identification using Pseudomonas spp. specific primer showed that 16 (94.1\%) isolates from CHB and 18 (90\%) isolates from UBTH were confirmed. The $16 \mathrm{~S}$ DNA sequencing revealed that $P$. aeruginosa strain $\mathrm{H} 25883$ was dominant in both locations.

Conclusion: High antibiotic resistance among $P$. aeruginosa isolates was established in our study. PCR technique revealed a more reliable method of bacterial identification. $\mathrm{H}_{25883}$ strain of $P$. aeruginosa is the prevalent strain in both locations and it should be given attention in nosocomial surgical wound infections.

Keywords: $16 S$ rRNA sequencing, molecular characterisation, Pseudomonas aeruginosa, wound infection, nosocomial infections 


\section{Introduction}

Post-surgical wound infection is the major source of nosocomial infection in surgical patients, accounting for $39.9 \%$ of all infections. It mainly causes post-operative morbidity, resulting in longer hospital stay, increased hospital bill and incidences of postoperative death. Generally, wound infections are a result of wound contamination caused by endogenous bacteria from the patient's skin, mucous membrane or hollow viscera (1). The development of an infection in any wound is subjective largely to the virulent nature of the microorganism and immunity of the patient. Nevertheless, when pus oozes from a closed surgical opening along with signs of inflammation in the adjoining tissues, it is referred to as wound infection $(2,3)$.

Pseudomonas aeruginosa ( $P$. aeruginosa) is a gram-negative bacterium. It is nonsporous, motile and a facultative anaerobe. It is accountable for a wide range of diseases in both humans and animals (4). Generally, $P$. aeruginosa is an opportunistic and nosocomial infectious organism that could develop infections in burns, injury, surgical wounds and in immunocompromised subjects $(5,6)$. Incidences of $P$. aeruginosa infections are on the rise worldwide due to their mechanisms of survival, adaptation and resistance to different types of antibiotics (7). Wound infection caused by $P$. aeruginosa is considered a major cause of morbidity and mortality (8). The immense use of routine broad-spectrum antibiotics has increased the resistance of $P$. aeruginosa to clinical drugs, which has led to serious therapeutic problems (9). Thus, timely and precise diagnosis is essential for proper treatment and also to control future disease outbreaks. A wide range of diagnostic methods have been established for $P$. aeruginosa identification. They include phenotypic methods (10), electrochemical techniques (11) such as enzyme-linked immunosorbent assay (12), and molecular methods such as polimerase chain reaction (PCR) (13), real-time PCR (14, 15 ), and particularly $16 \mathrm{~S}$ DNA sequencing (16). Despite the existing and extensive reports on the prevalence of P.aeruginosa in hospital environments, there is still a paucity of research finding on molecular identification of multidrug $P$. aeruginosa strains from surgical wounds particularly in Benin City, Nigeria. Therefore, the present study sought to identify prevailing multidrug $P$.aeruginosa strains from the surgical wound using the 16S rRNA sequencing technique.

\section{Methods}

\section{Sample Collection}

A total of 284 random swab samples of post-operative surgical wound patients (142 from each) were collected from Central Hospital Benin (CHB) and University of Benin Teaching Hospital (UBTH), Benin City.

\section{Bacteriological Procedures/Identification of Isolates}

All samples were aseptically inoculated onto blood, MacConkey, nutrient agar and incubated aerobically at $37^{\circ} \mathrm{C}$ for $24 \mathrm{~h}$ and checked for colonial growth. Different $P$. aeruginosa strains were isolated from surgical wound samples. They were further identified by using morphological and physiological test (gram staining; oxidase; indole, methyl red, Voges-Proskauer and citrate [IMViC] test; nitrate reduction test and catalase; carbohydrate fermentation test for glucose, maltose, lactose, galactose and sucrose). All specimens were processed at the Lahor Research Laboratories, Benin City, Nigeria using standard microbiological methods. All isolates were identified using conventional techniques as described by Cheesbrough (17).

\section{Screening Method for Multidrug Resistant $P$. aeruginosa}

Antibiotic screening of Pseudomonas spp. isolated from surgical wound swab were carried out with commonly used antibiotic by the Kirby-Bauer disk diffusion method to identify multidrug resistant (MDR) Pseudomonas spp. The following antibiotic disks were used: augmentin (AUG $30 \mu \mathrm{g}$ ), ofloxacin (OFL $5 \mu \mathrm{g}$ ), cefixime (CXM $5 \mu \mathrm{g}$ ), gentamycin (GEN $30 \mu \mathrm{g}$ ), cefuroxime (CRX $30 \mu \mathrm{g}$ ), ceftazidime (CAZ 30 $\mu \mathrm{g}$ ), ciprofloxacin (CPR $5 \mu \mathrm{g}$ ), nitrofurantion (NIT $300 \mu \mathrm{g}$ ) and interpretation of zones of inhibition according to the Clinical and Laboratory Standards Institute guidelines (18).

\section{Bacteria Genomic DNA Extraction}

All multidrug resistant P. aeruginosa isolates were subcultured overnight in LuriaBertani broth (Merck, Germany) and DNA was extracted from typical colonies of P. aeruginosa strains using Zymo research DNA extraction kits 
(Irvine, CA, USA), according to manufacturer's instructions.

\section{Polymerase Chain Reaction Technique}

PCR was employed for the amplification of Pseudomonas spp. and 16S rRNA primers separately (Table 1) in ABI9700 thermal cycler PCR machine at Lahor Research Laboratories, Benin City, Nigeria. All primers and PCR master mix 2× (New England Biolab, USA) was purchased from lnqaba Biotech, Hartfield, South Africa and was used according to the manufacturer's instruction. The PCR run was performed in $25 \mu \mathrm{L}$ reaction mixture containing one part of Quick load (2×) master mix, $1.25 \mu \mathrm{L}$ of each forward and reverse primer $(20 \mu \mathrm{M})$, 5.0 $\mu \mathrm{L}$ of nuclease free water and $5 \mu \mathrm{L}$ of DNA template was added last. The PCR was started immediately as follows: Initial denaturation at $94{ }^{\circ} \mathrm{C}$ for $3 \mathrm{~min}$; denaturation at $94{ }^{\circ} \mathrm{C}$ for $30 \mathrm{sec}$; annealing at $50^{\circ} \mathrm{C}$ and $54{ }^{\circ} \mathrm{C}$ for $30 \mathrm{sec}$, respectively; extension at $72{ }^{\circ} \mathrm{C}$ for $1 \mathrm{~min}$, for 35 cycles; final extension at $72{ }^{\circ} \mathrm{C}$ for $10 \mathrm{~min}$; and final holding at $4{ }^{\circ} \mathrm{C}$ forever. The amplified PCR products $(10 \mu \mathrm{L})$ were separated on a $1.0 \%$ agarose gel containing ethidium bromide in Tris/ Borate/EDTA (TBE) buffer. Electrophoresis was performed at 90 volts for 60 min. Products were visualised in a UV transilluminator and photographed. Amplicon weights were calculated using size maker.

\section{PCR Product Purification and Sequencing}

Amplification and sequencing were done as described by Agbonlahor et al. (21), with the following modifications: Purification was done with the Applied Biosystems Incorporation (ABI) V3.1 Big dye kit according to manufacturer's instructions. The labeled products were then cleaned with the Zymo Seq clean-up kit (USA) in accordance with manufacturer's instructions. The ultra-pure DNA was sequenced with ABI3500XL analyser at Functional Bioscience, Madison, USA. Sequences data generated were analysed with Geneious version 9.0.5 and phylogenetic tree were constructed using neighbour-joining method as described by Agbonlahor et al. (21).

\section{Statistical Analysis}

Percentage multiple drug resistance isolates was calculated using the following equation:

$\%=\frac{\text { Number of MDR isolates from location }}{\text { Total number of isolates from location }} \times \frac{100}{1}$

\section{Results}

Biochemical Characterisation of Bacterial Isolates and Distribution of Etiologic Agents of Surgical Wound Infection

Two hundred and eighty-four postoperative wound swabs specimens were collected from patients in CHB and UBTH both in Benin City and analysed. A total of 99 (35\%) of patients studied had wound infections. Phenotypic identification of these bacterial isolates using morphological and biochemical tests revealed rod shaped, Gram negative, motile, catalase, oxidase, glucose and citrate positive isolates as well lactose, urease, mannitol, coagulase negative which was suggestive of Pseudomonas spp. as shown in Table 2. From both locations, 62 (21.8\%) patients (27 from CHB and 35 from UBTH) had Pseudomonas spp., 18 (6.3\%) patients ( 8 from CHB and 10 from UBTH) had Escherichia coli, 12 (4.2\%) patients (5 from CHB and 7 from UBTH) had Staphylococcus aureus. Pseudomonas spp. is the most isolated pathogen.

\section{Antibiotic Susceptibility and Resistance}

Antibiotic susceptibility profile of all Pseudomonas spp. from both locations showed that 17 (63.0\%) from $\mathrm{CHB}$ and 20 (57.1\%) from UBTH had MDR ability against the tested antibiotics. Ceftazidime recorded highest

Table 1. Sequence information of primer used

\begin{tabular}{|c|c|c|c|c|c|}
\hline $\mathbf{S} / \mathbf{N}$ & $\begin{array}{l}\text { Primer } \\
\text { name }\end{array}$ & Primer sequence ( 5 ' to $3^{\prime}$ ) & $\begin{array}{l}\text { Target gene } \\
\text { or region (s) }\end{array}$ & $\begin{array}{c}\text { Product } \\
\text { length (bp) }\end{array}$ & Reference \\
\hline 1 & $\begin{array}{l}\text { PA-GS-F } \\
\text { PA-GS-R }\end{array}$ & $\begin{array}{l}\text { GACGGGTGAGTAATGCCTA } \\
\text { CACTGGTGTTCCTTCCTATA }\end{array}$ & Pseudomonas spp. & 618 & (19) \\
\hline 2 & $\begin{array}{l}27 \mathrm{~F} \\
1492 \mathrm{R}\end{array}$ & $\begin{array}{l}\text { AGAGTTTGATCMTGGCTCAG } \\
\text { CGGTTACCTTGTTACGACTT }\end{array}$ & 16S rRNA & 1500 & (20) \\
\hline
\end{tabular}


Table 2. Morphological and biochemical characterisation of bacterial isolates

\begin{tabular}{|c|c|c|c|c|}
\hline Characterisation & Group A & Group B & Group C & Group D \\
\hline Shape & Rods & Rods & Rods & Cocci \\
\hline Gram's staining & -ve & -ve & -ve & $+\mathrm{ve}$ \\
\hline Motility & Motile & Motile & Motile & Non- motile \\
\hline Catalase & + ve & + ve & $+\mathrm{ve}$ & $+\mathrm{ve}$ \\
\hline Oxidase & -ve & + ve & -ve & -ve \\
\hline Glucose & +ve & + ve & + ve & + ve \\
\hline Sucrose & -ve & -ve & -ve & $+\mathrm{ve}$ \\
\hline Maltose & + ve & -ve & -ve & $+\mathrm{ve}$ \\
\hline Lactose & $+\mathrm{v}$ & -ve & -ve & $+\mathrm{ve}$ \\
\hline Oxidation fermentation & Fermenter & Oxidiser & Facultative anaerobes & Fermenter \\
\hline Mannitol & $+\mathrm{ve}$ & -ve & -ve & + ve \\
\hline Urease & -ve & -ve & + ve & $+\mathrm{ve}$ \\
\hline Citrate & -ve & + ve & -ve & $+\mathrm{ve}$ \\
\hline Nirate & +ve & + ve & +ve & +ve \\
\hline Indole & + ve & -ve & -ve & -ve \\
\hline Methyl red & $+\mathrm{ve}$ & -ve & + ve & -ve \\
\hline Coagulase & -ve & -ve & -ve & $+\mathrm{ve}$ \\
\hline Bacteria suspected & $\begin{array}{l}\text { Escherichia } \\
\text { coli }\end{array}$ & $\begin{array}{l}\text { Pseudomonas } \\
\text { spp. }\end{array}$ & Proteus mirabilis & $\begin{array}{c}\text { Staphylococcus } \\
\text { aureus }\end{array}$ \\
\hline
\end{tabular}

Notes: +ve = positive; $-\mathrm{ve}=$ negative; Group A, B, C, D = different isolates

Table 3. Distribution of etiologic agents of surgical wound infection

\begin{tabular}{clrc} 
S/N & Bacterial isolates & UBTH & CHB \\
1 & Pseudomonas spp. & 35 & 27 \\
2 & Escherichia coli & 8 & 10 \\
3 & Proteus mirabilis & 4 & 3 \\
4 & Staphylococcus aureus & 7 & 5 \\
\hline & Total & 54 & 45 \\
\hline
\end{tabular}

resistance $(85.2 \%)$ in isolates from $\mathrm{CHB}$ while isolates from UBTH showed highest resistance against nitrofuration (77.1\%) followed by (68.6\%) observed for gentamycin (Table 4).

\section{Amplification of Pseudomonas spp.}

PCR amplification using Pseudomonas spp. specific primer set indicated that 16 (94.1\%) suspected Pseudomonas spp. isolates from CHB and 18 (90.0\%) suspected Pseudomonas spp. isolates from UBTH were confirmed to be Pseudomonas spp. with bands at 618 base pair which were clearly visible under UV transilluminator. In addition, a similar band was also seen for positive control strain with American type culture collection number 27852. As expected, no band was seen in the negative control where nuclease free water was used instead of bacterial DNA as shown in Figures 1-4.

\section{S rRNA Sanger Sequencing of Pseudomonas spp.}

Sequencing of Pseudomonas spp. isolates were carried out to further identify the MDR Pseudomonas spp. isolates to the strain level. Phylogenetic tree of isolates revealed different $P$. aeruginosa strains for all 34 Pseudomonas spp. as exemplified in Figures 5-8.

\section{Prevalence of MDR P. aeruginosa Strains from $C H B$ and $U B T H$}

The percentage occurrence of MDR $P$. aeruginosa strains among sequenced isolates from $\mathrm{CHB}$ revealed that $P$. aeruginosa strains H25883 had the highest percentage occurrence of $18.75 \%$ followed by $P$. aeruginosa strains 
Original Article | Prevailing multidrug $P$. aeruginosa strains

Table 4. Susceptibility profile of suspected Pseudomonas spp. isolates to tested antibiotics

\begin{tabular}{|c|c|c|c|c|c|}
\hline \multirow[t]{2}{*}{ Class of antibiotics } & \multirow[t]{2}{*}{ Type of antibiotics } & \multicolumn{2}{|c|}{$\begin{array}{c}\text { CHB } \\
\boldsymbol{n}=\mathbf{2 7} \\
\end{array}$} & \multicolumn{2}{|c|}{$\begin{array}{l}\text { UBTH } \\
n=35 \\
\end{array}$} \\
\hline & & $\mathbf{R}$ & $\mathbf{S}$ & $\mathbf{R}$ & $\mathbf{S}$ \\
\hline Penicillin & Augmentin $(30 \mu \mathrm{g})$ & 17 & 10 & 22 & 13 \\
\hline Aminoglycoside & Gentamycin $(30 \mu \mathrm{g})$ & 19 & 8 & 24 & 11 \\
\hline \multirow[t]{3}{*}{ Cephalosporin } & Ceftazidime $(30 \mu \mathrm{g})$ & 23 & 4 & 21 & 14 \\
\hline & Cefuroxime $(30 \mu \mathrm{g})$ & 19 & 8 & 20 & 15 \\
\hline & Cefixime $(5 \mu \mathrm{g})$ & 22 & 5 & 20 & 15 \\
\hline Nitrofuran & Nitrofuration $(300 \mu \mathrm{g})$ & 18 & 9 & 27 & 8 \\
\hline \multirow[t]{2}{*}{ Quinolones } & Ofloxacin $(5 \mu \mathrm{g})$ & 16 & 11 & 18 & 17 \\
\hline & Ciprofloxacin $(5 \mu \mathrm{g})$ & 13 & 14 & 13 & 22 \\
\hline
\end{tabular}

Notes: $n=$ number of bacteria tested; $\mathrm{R}=$ number of bacteria resistant; $\mathrm{S}=$ number of bacteria sensitive

Loading wells

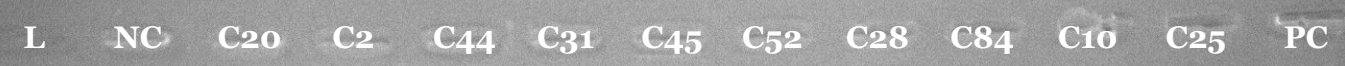

$1517 \mathrm{bp}$

$100 b p$

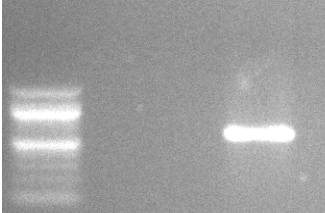$$
\text { (10) }
$$

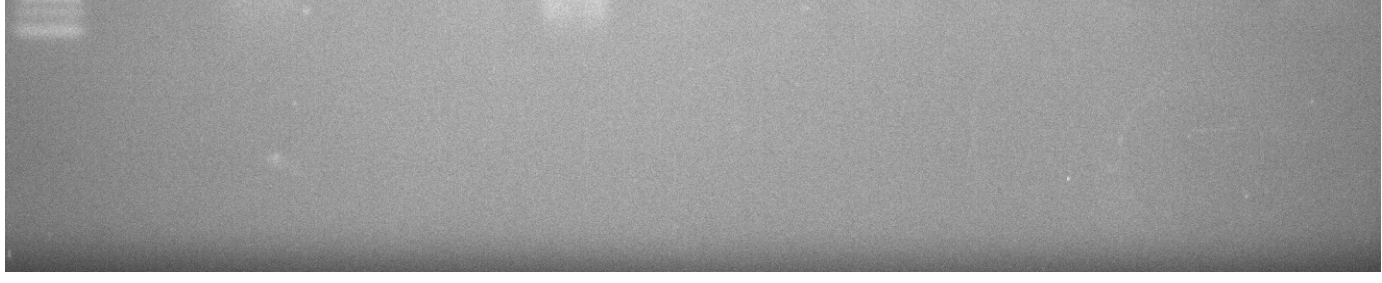

Figure 1. Molecular confirmation of Pseudomonas spp. using PCR technique. Isolates C20, C44, C31, C45, C52, C28, C84, C10 and C92 are positive control with bands at 618bp, isolate C2 is not Pseudomonas spp.

Notes: $\mathrm{NC}=$ negative control; $\mathrm{PC}$ is a positive control strain with American type culture collection number 27852

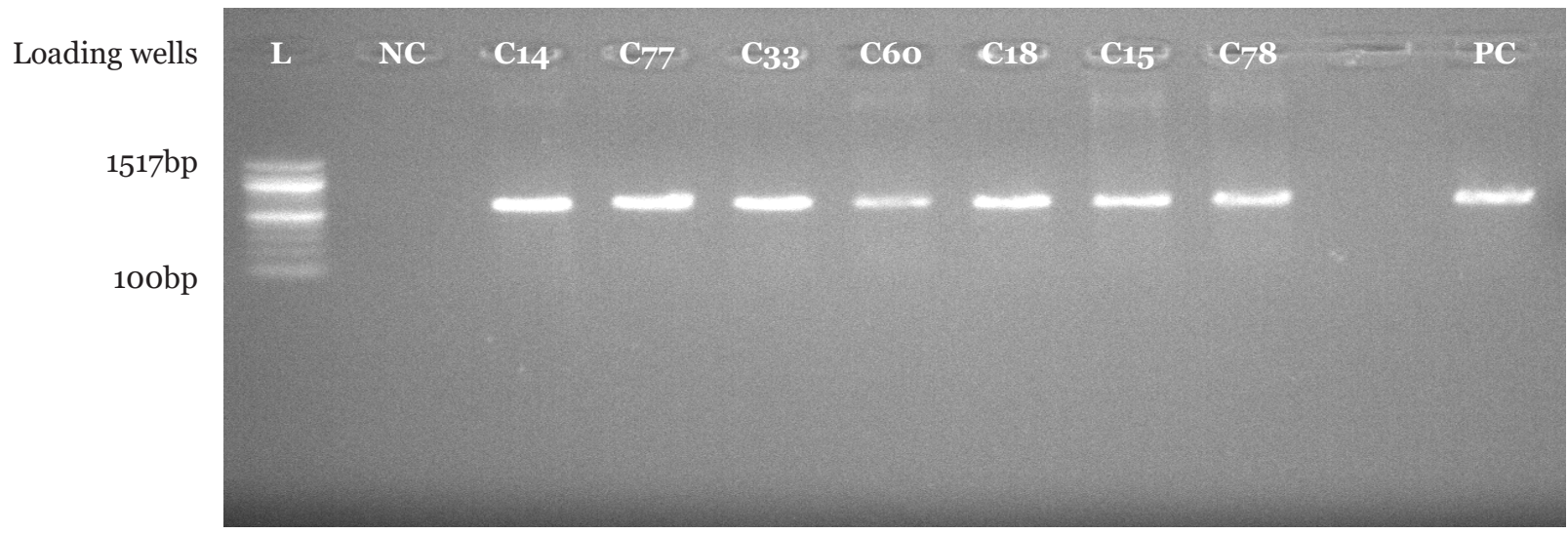

Figure 2. Molecular confirmation of Pseudomonas spp. using PCR technique. Isolates C14, C77, C33, C60, C18, $\mathrm{C} 15$ and $\mathrm{C} 78$ are positive control with bands at 618bp

Notes: $\mathrm{NC}=$ negative control; $\mathrm{PC}=$ positive control strain with American type culture collection number 27852 




Figure 3. Molecular confirmation of Pseudomonas spp. using PCR technique. Isolates U1, U5, U10, U41, U22, U12, U65, U80 and U25 are positive with bands at 618bp. Isolates U34 is negative control for Pseudomonas sp. and PC is a positive control strain with American type culture collection number 27852

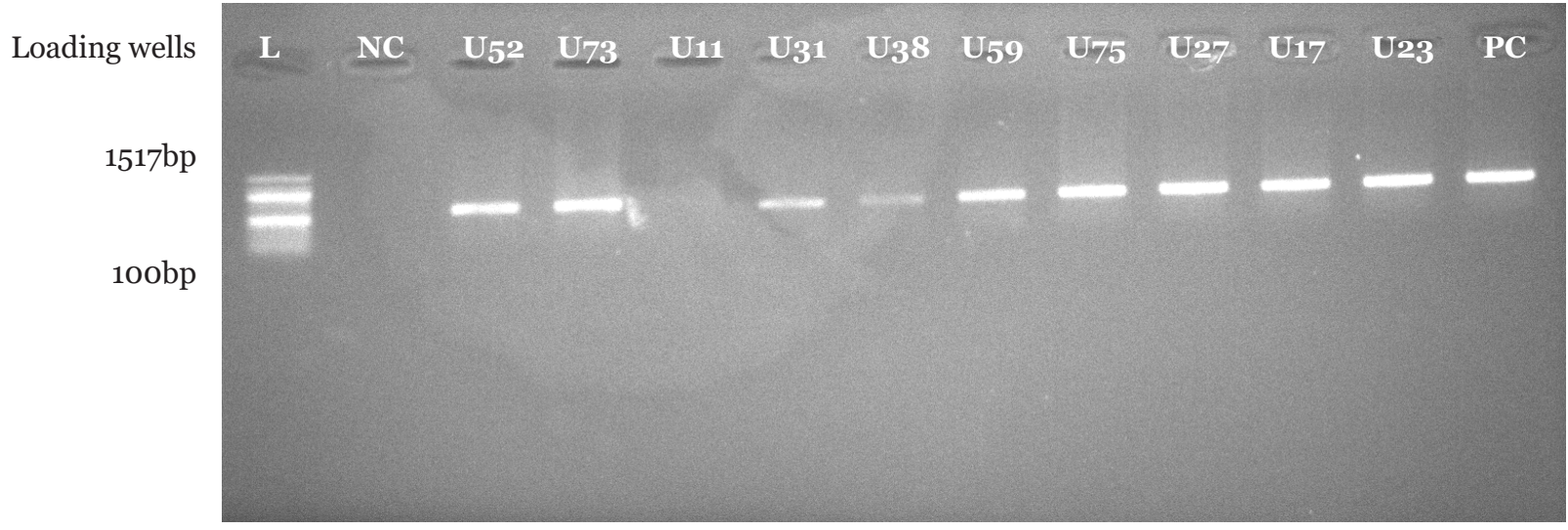

Figure 4. Molecular confirmation of Pseudomonas spp. using PCR technique. Isolates U52, U73, U31, U38, U59, U75, U27, U17 and U23 are positive with bands at $618 \mathrm{bp}$. NC is a negative control; isolates U11 is negative control for Pseudomonas spp. and PC is a positive control strain with American type culture collection number 27852

AR7-520 and PAoo6 with $12.5 \%$, respectively (Figure 9). In the same vein, P. aeruginosa strains $\mathrm{H} 25883$ also recorded the highest percentage occurrence of $(22.22 \%)$ in UBTH followed by P.aeruginosa strains KAR21 with $11 \%$ as shown in Figure 10.

\section{Discussion}

P. aeruginosa, a non-fermentative gramnegative bacterium, is currently the second most widespread nosocomial bacterium, after Acinetobacter species (22). P. aeruginosa broadly exists in hospital environments (23) and medical equipment (22). Infections caused by $P$. aeruginosa are particularly tough to treat as the microbe has intrinsic resistance to a large number of antimicrobial agents. Furthermore, with the acquisition of antibiotic-resistant genes, it is becoming more difficult to cure infections caused by this organism (24).

Despite the existing and extensive reports on the prevalence of $P$. aeruginosa in hospital environments, there is still a paucity of research finding on molecular identification of multidrug $P$. aeruginosa strains from surgical wounds, particularly in Benin City, Nigeria. Hence, data from the present study revealed that the P.aeruginosa strain showed the highest antibiotic resistance to ceftazidime in isolates from $\mathrm{CHB}$ and nitrofurantoin in isolates from the UBTH. Lowest resistance was observed for 
Original Article | Prevailing multidrug P. aeruginosa strains

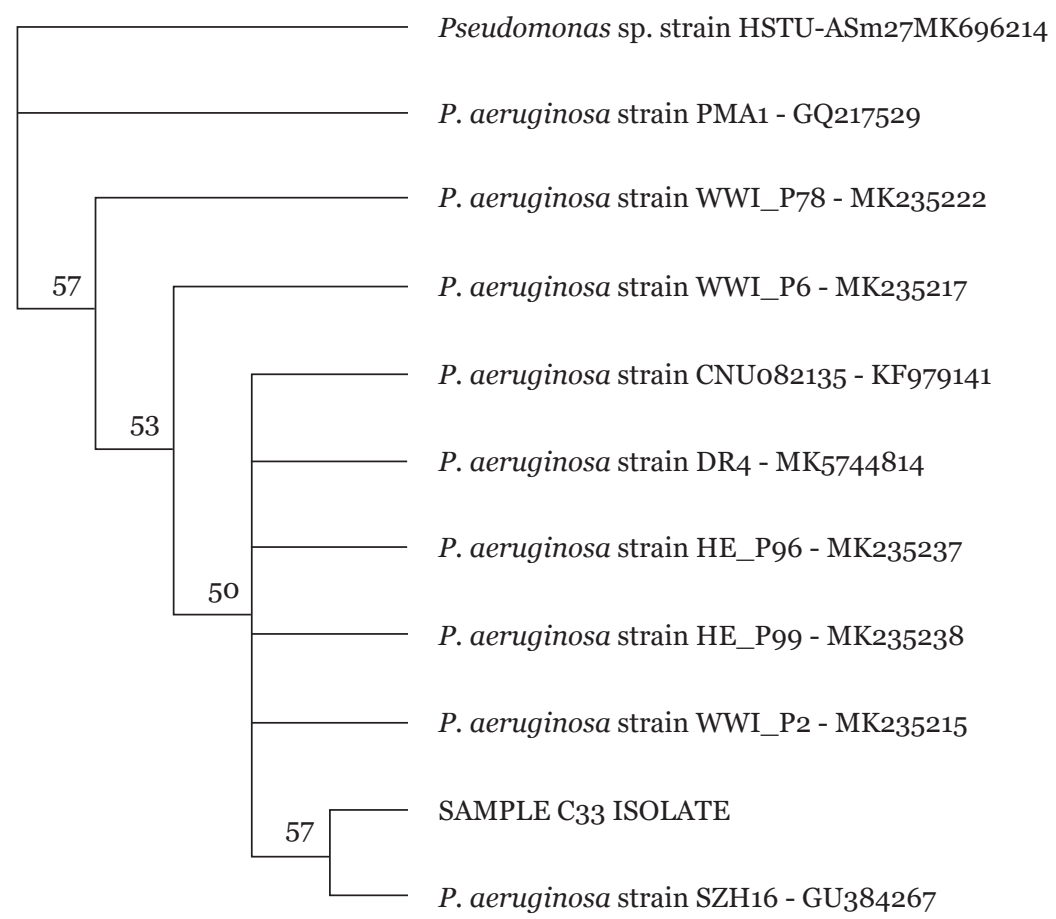

Figure 5. Phylogenetic analysis of clinical isolate based on the nucleotide sequence of part of the 16S rRNA. The phylogenetic tree was constructed by the neighbour-joining method programme in the Geneious package (version 9.0.5). The numbers at the forks show the numbers of occurrences of the repetitive groups to the right out of 100 bootstrap samples. Sample C33 isolate show close relation to NCBI-Blast $P$. aeruginosa strain SZH16 with accession number GU384267

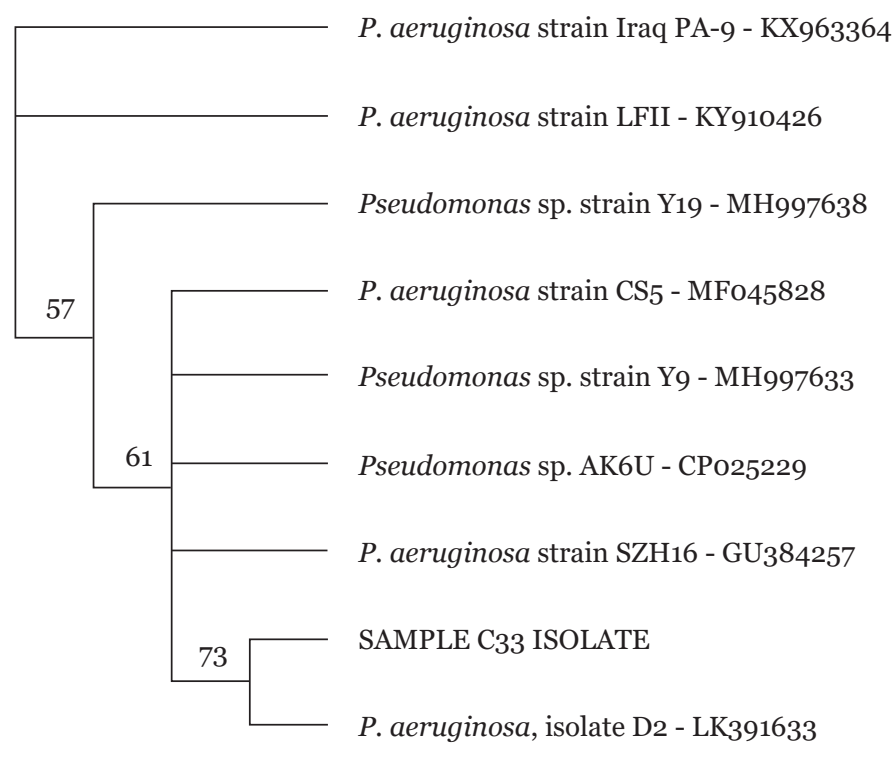

Figure 6. Phylogenetic analysis of clinical isolate based on the nucleotide sequence of part of the 16S rRNA. The phylogenetic tree was constructed by the neighbour-joining method programme in the Geneious package (version 9.0.5). The numbers at the forks show the numbers of occurrences of the repetitive groups to the right out of 100 bootstrap samples. Sample $\mathrm{C}_{7} 8$ isolate show close relation to NCBI-Blast $P$. aeruginosa isolate D2 with accession number LK391633 


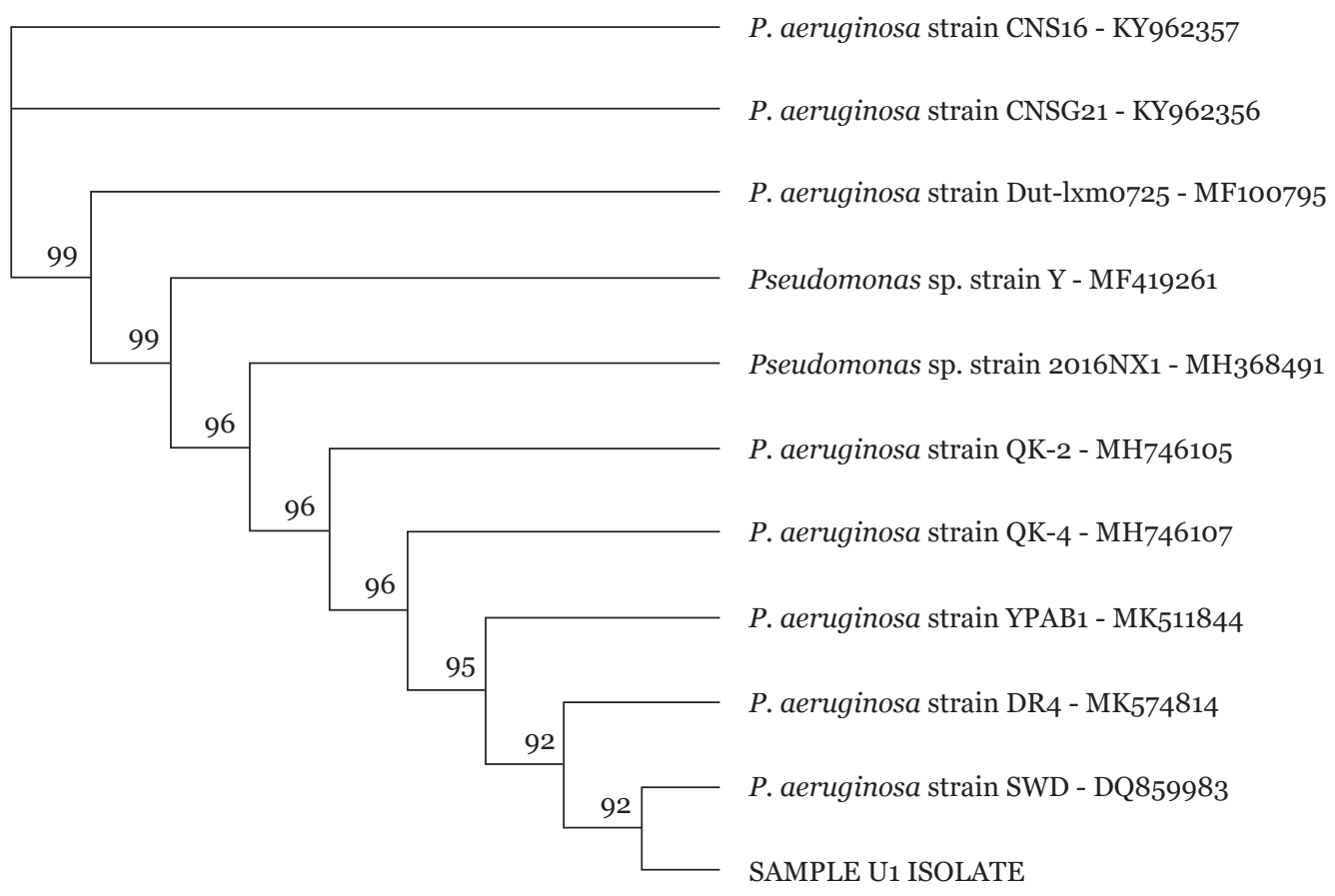

Figure 7. Phylogenetic analysis of clinical isolate based on the nucleotide sequence of part of the 16S rRNA. The phylogenetic tree was constructed by the neighbour-joining method programme in the Geneious package (version 9.0.5). The numbers at the forks show the numbers of occurrences of the repetitive groups to the right out of 100 bootstrap samples. Sample U1 isolate show close relation to NCBI-Blast $P$. aeruginosa strain SWD with accession number DQ859983

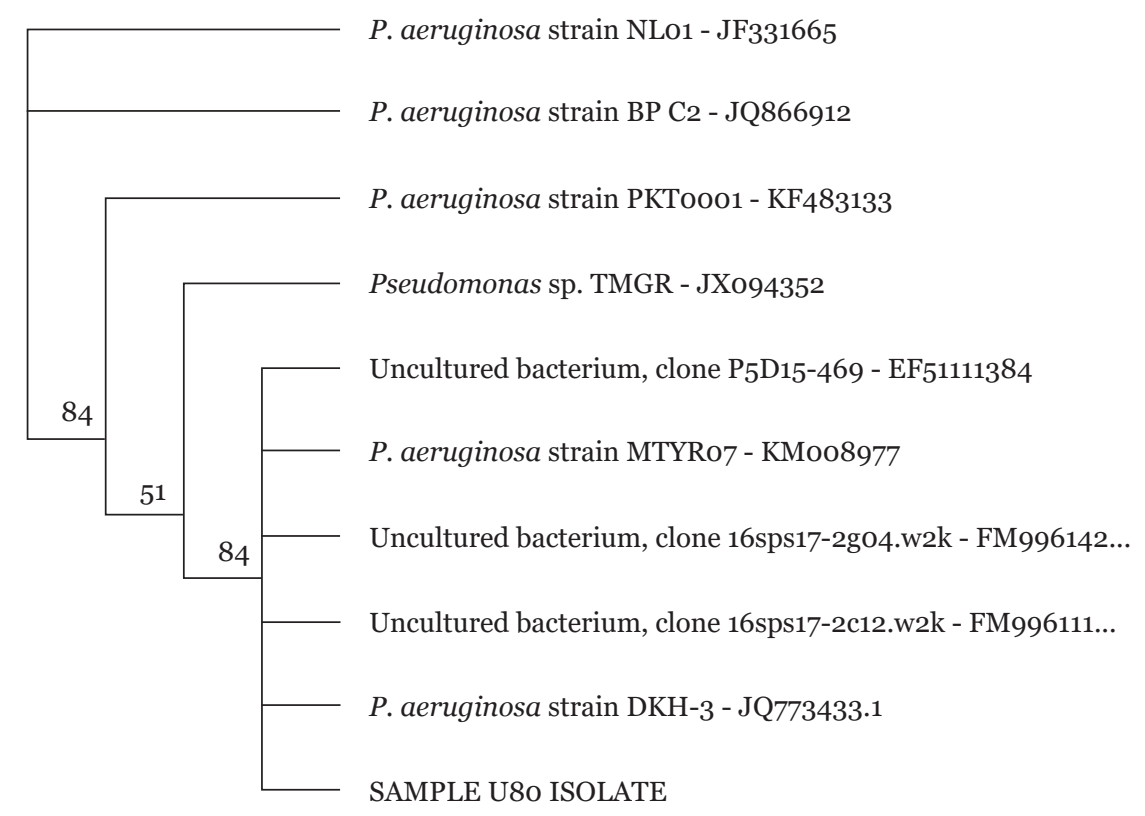

Figure 8. Phylogenetic analysis of clinical isolate based on the nucleotide sequence of part of the 16S rRNA. The phylogenetic tree was constructed by the neighbour-joining method programme in the Geneious package (version 9.0.5). The numbers at the forks show the numbers of occurrences of the repetitive groups to the right out of 100 bootstrap samples. Sample U80 isolate show close relation to NCBI-Blast $P$. aeruginosa strain DKH-3 with accession number JQ773433.1 




MDR $P$. aeruginosa strains

Figure 9. Percentage occurrence of MDR P. aeruginosa strains isolated from surgical wound in CHB

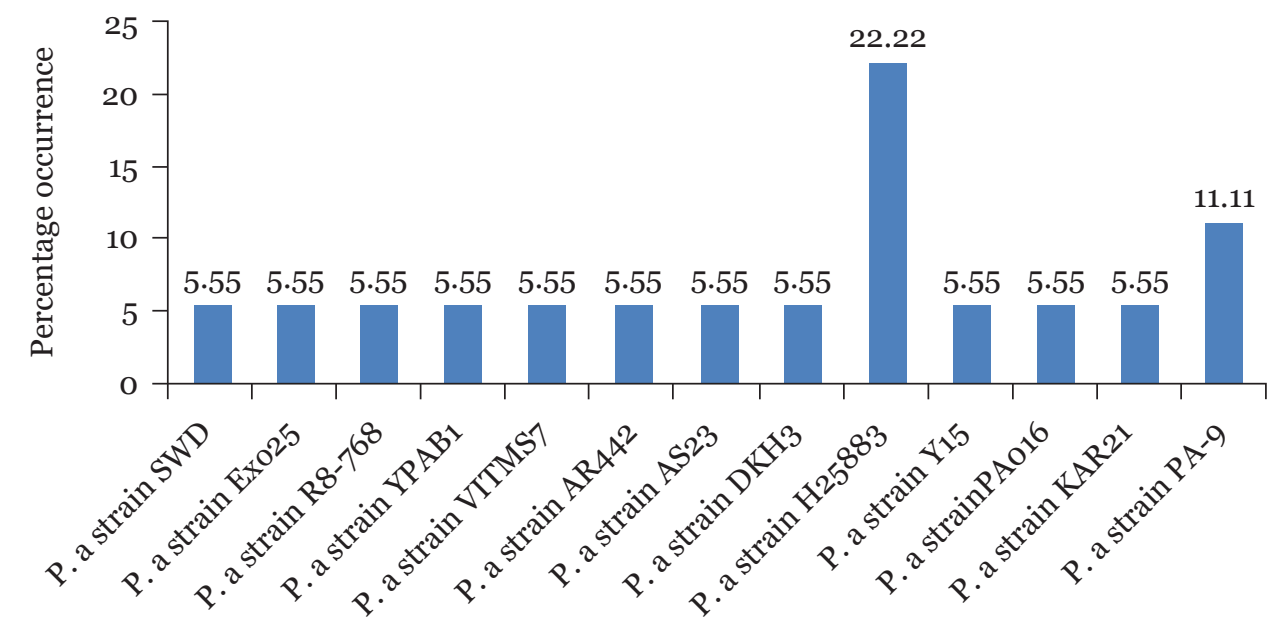

MDR P. aeruginosa strains

Figure 10. Percentage occurrence of MDR P. aeruginosa strains isolated from surgical wound in UBTH

ciprofloxacin for both locations. In comparison to previously reported data, the result of the present study corroborates the finding of Carroll et al. (25) and Leone et al. (26) that also reported a high antibiotic resistance rate towards ceftazidime and gentamycin antibiotics in both clinical and environmental isolates. Additionally, the study of Ruiz et al. (27) reported that clinical bacterial isolates are less susceptible to antimicrobial agents than environmental bacterial isolates due to their selective action (27).

Molecular characterisation of Pseudomonas spp. isolated from surgical wound infections specimens from both locations showed that 16
(94.1\%) out of 17 isolates were confirmed to be Pseudomonas spp. in CHB, while 18 (90\%) out of 20 were confirmed to be Pseudomonas spp. with bands at 618 base pair for test isolates and positive control strains. The above-mentioned genus-specific PCR assays indicated that three clinical isolates had been misidentified using phenotypic laboratory methods. This signifies the efficiency of the molecular characterisation method over phenotypic characterisation. With regard to a study by Spilker et al. (19), the genusspecific PCR assays indicated that several of the 66 clinical isolates were misidentified by the referring laboratories (19). 
Sequence analysis of $16 \mathrm{~S}$ rRNA is now being used as a taxonomic 'gold standard' in determining the phylogenies of bacterial species (28). The 16S rRNA gene sequences comprise hypervariable regions with high conservation that can differentiate species-specific signature sequences helpful in the classification of bacteria (29, 30). Going forward, 34 (91.9\%) Pseudomonas spp. were further examined by $16 \mathrm{~S}$ rRNA sequence analysis, and in each case, the PCR assay results were consistent. Thus, when this set of isolates was assessed against the $16 \mathrm{~S}$ rRNA sequence, the sensitivity and specificity of both PCR assays were again $100 \%$. It has also been reported that selective amplification of Pseudomonas 16S rRNA analysis is used to detect and differentiate Pseudomonas species from clinical and environmental samples (30). The present results agree with the finding of Didelot et al. (32) who reported that $16 \mathrm{~S}$ rRNA gene sequencing is now common in medical microbiology as a quick and inexpensive alternative to phenotypic approaches of bacterial identification.

The result from the phylogenetic trees showed that MDR P. aeruginosa strain $\mathrm{H} 25883$ was the predominant strain in both locations (CHB and UBTH) with $18.75 \%$ and $22.22 \%$, respectively. P. aeruginosa strains AR7520 and PAoo6 with $12.5 \%$ were observed in $\mathrm{CHB}$, making it the second predominant strains. However, many studies reported that $P$. aeruginosa has been mostly isolated from post-operative surgical wounds regardless of the site of infection and location of samples as a result of its high survival uniqueness in the hospital setting $(33,34)$. It has been ranked second among nosocomial disease-causing microbes. They are isolated from hospitals frequently, contaminating hospital equipment such as sinks used for wound dressing and other surgical tools. Furthermore, many antimicrobialresistant strains continue to exist in apparently sterile hospital equipment, therefore, making it a precarious nosocomial pathogen broadly dispersed in the hospital environments where they are most difficult to eliminate (35).

The 16S rRNA sequence analysis on all identified MDR isolates was carried out and the sequence data confirmed the PCR results. Though our PCR and DNA sequence analyses showed bacterial isolates that were misidentified by phenotypic testing, we must point out that this study was not intended to determine the incidence of misidentification of post-surgical wound bacterial isolates neither to evaluate the relative precision of different phenotypic identification systems. Both assays have 100\% sensitivity and specificity for their intended targets. We have also established the utility of these PCR assays in precisely identifying $P$. aeruginosa strains among isolates not correctly identified by phenotypic analyses. These assays should serve as a valuable accessory in the evaluation of gram-negative non-fermenting bacteria recovered from surgical wound isolates.

\section{Conclusion}

The results obtained from our study revealed that the 16S rRNA-based PCR and sequencing are highly sensitive, precise and consistent for the identification of $P$. aeruginosa strains isolated from post-operative surgical wound infections than conventional bacterial phenotypic methods. Our finding further highlights the use of DNA sequencing of the $16 \mathrm{~S}$ rRNA gene as an effective tool to study bacterial phylogeny and taxonomy associations between bacteria and bacterial detection as well. Thus, early identification and control of this pathogen have become increasingly important.

\section{Acknowledgements}

Our sincere gratitude to Professor Dennis E. Agbonlahor, MD/CEO of Lahor Research Laboratories and Medical Centre, Head of Laboratory Department, Dr Joy Ehiaghe for her encouragement and the entire staff of Lahor Research Laboratories and Medical Centre for their contributions.

\section{Ethics of Study}

Approval was obtained from the UBTH and CHB ethical committee, and all the patients consented to collection of samples after being educated on the objectives of the study.

\section{Conflict of Interest}

None.

\section{Funds}

None. 


\section{Authors' Contributions}

Conception and design: EOA, $\mathrm{SOH}$

Analysis and interpretation of the data: EOA, NSU

Drafting of the article: EOA

Critical revision of the article for important

intellectual content: $\mathrm{SOH}, \mathrm{NSU}$

Final approval of the article: EOA, SOH, NSU

Provision of study materials or patients: EOA

Statistical expertise: EOA

\section{Correspondence}

Dr Eremwanarue Osagie Aibuedefe

BSc (University of Calabar), MSc (University of

Benin), PhD (University of Benin)

Department of Plant Biology and Biotechnology,

University of Benin, PMB, 1090 Ugbowo,

Benin City, Nigeria.

Tel: +2348037945407

E-mail: eremwanarueaibuedefe@yahoo.com

\section{References}

1. Mohammed A, Adeshina GO, Ibrahim YKE. Retrospective incidence of wound infections and antibiotic sensitivity pattern: a study conducted at the Aminu Kano Teaching Hospital, Kano, Nigeria. Int $J$ Med Sci. 2013;55:60-66. https://doi.org/10.5897/IJMMS12.114

2. Heggars JP. Assessing and controlling wound infections. Clin Plas Surg. 2003;30(1):25-35. https://doi.org/10.1016/s0094-1298(02)00072-x

3. Anaya DA, Dellinger EP. Challenges in the prevention of surgical site infections. Infections in Medicine. 2006;23:12-26.

4. Pallavali RR, Degati VL, Dakshayani L, Reddy MC, Durbaka VRP. Isolation and in vitro evaluation of bacteriophages against MDRbacterial isolates from septic wound infections. PLoS One. 2017;12(7):e0179245. https://doi .org/10.1371/journal.pone.0179245

5. Garbe D, Thiel IV, Mootz HD. Protein transsplicing on an M13 bacteriophage: towards directed evolution of a semisynthetic split intein by phage display. J Pept Sci. 2010;16(10):575581. https://doi.org/10.1002/psc.1243
6. Kwiatek M, Mizak L, Parasion S, Gryko R, Olender A, Niemcewicz M. Characterization of five newly isolated bacteriophages active against Pseudomonas aeruginosa clinical strains. Folia Microbiol (Praha). 2015;60(1):7-14. https://doi.org/10.1007/s12223-014-0333-3

7. Moradali MF, Ghods S, Rehm BH. Pseudomonas aeruginosa lifestyle: a paradigm for adaptation, survival, and persistence. Front Cell Infect Microbiol. 2017;7(39):1-29. https://doi.org/10 $.3389 /$ fcimb.2017.00039

8. Ehiaghe JI, Nwobu RAU, Ehiaghe FA, Agbakoba NR, Agbonlahor DE, Uwabor CI. Plasmid profiling of multidrug resistant bacteria isolates from surgical site infection in Nigeria. Am. $J$. Biotechnol. Mol. Sci. 2016;5(1):23-32

9. Peng Y, Bi J, Shi J, Li Y, Ye X, Chen X. Multidrug- resistant Pseudomonas aeruginosa infections pose growing threat to health careassociated infection control in the hospitals of Southern China: a case-control surveillance study. Am J Infect Control. 2014;42:1308-1311. https://doi.org/10.1016/j.ajic.2014.08.006

10. Jin WY, Jang SJ, Lee MJ, Park G, Kim MJ, Kook JK. Evaluation of VITEK2, MicroScan, and Phoenix for identification of clinical isolates and reference strains. Diagn Microbiol Infect Dis. 2011;70:442-447. https://doi.org/10.1016/j .diagmicrobio.2011.04.013

11. Webster TA, Sismaet HJ, Conte JL, Chan IP, Goluch ED. Electrochemical detection of Pseudomonas aeruginosa in human fluid samples via pyocyanin. Biosens Bioelectron. 2014;6o:265-270. https://doi.org/10.1016/j.bios .2014 .04 .028

12. Mauch RM, Rossi CL, Ribeiro JD, Ribeiro AF, NolascodaSilva MT, Levy CE. Assessment of IgG antibodies to Pseudomonas aeruginosa in patients with cystic fibrosis by an enzyme-linked immunosorbent assay (ELISA). Diagn Pathol. 2014;9:158. https://doi.org/10.1186/s1300o-014 $-0158-\mathrm{z}$

13. Aghamollaei H, Moghaddam MM, Kooshki H, Heiat M, Mirnejad R, Barzi NS. Detection of Pseudomonas aeruginosa by a triplex polymerase chain reaction assay based on lasI/RandgyrB genes. J Infect Public Health. 2015;8:314-322. https://doi.org/10.1016/j.jiph.2015.03.003 
14. Qin X, Emerson J, Stapp J, Stapp L, Abe P, Burns JL. Use of real-time PCR with multiple targets to identify Pseudomonas aeruginosa and other non-fermenting gram-negative bacilli from patients with cystic fibrosis. $J$ Clin Microbiol. 2003;41:4312-4317. https://doi.org/10.1128/ JCM.41.9

15. Deschaght P, VanDaele S, DeBaets F, Vaneechoutte M. PCR and the detection of Pseudomonas aeruginosa in respiratory samples of CF patients: a literature review. $J$ Cyst Fibros. 2011;10:293-297. https://doi.org/10.1016/j.jcf .2011 .05 .004

16. Chen L, Cai Y, Zhou G, Shi X, Su J, Guanwu C, et al. Rapid Sanger sequencing of the $16 \mathrm{~S}$ rRNA gene for identification of some common pathogens. PLoS One. 2014;9(2):e88886. https://doi.org/ 10.1371/journal.pone.0088886

17. Cheesbrough M. District laboratory practice manual in tropical countries, Part 2. New York: Cambridge University Press; 2000.

18. Clinical and Laboratory Standards Institute. Performance standards for antimicrobial susceptibility testing; Twenty first informational supplement. CLSI document M100-S21. Wayne, PA: Clinical and Laboratory Standards Institute; 2011.

19. Spilker T, Coenye T, Vandamme P, LiPuma JJ. PCR-based assay for differentiation of Pseudomonas aeruginosa from other Pseudomonas species recovered from cystic fibrosis patients. $J$ Clin Microbiol. 2004;42:2074-2079. https://doi.org/10.1128/ jcm.42.5.2074-2079.2004

20. Frank AJ, Reich CI, Sharma S, Weisbaum JS, Wilson BA, Olsen GJ. Critical evaluation of two primers commonly used for amplification of bacterial 16S rRNA genes. Appl Environ Microbiol. 2008;74(8):2461-2470. https://doi. org/10.1128/AEM.02272-07

21. Agbonlahor DE, Ehiaghe JI, Eremwanarue OA, Ehiaghe AF, Oviasogie FE, Iyen R, et al. A primal incrimination of Cedecea davisae with postprostatectomy urinary tract infection in Nigeria. International Journal of Biological and Chemical Science. 2018;12(2):676-688.
22. Dong D, Zou D, Liu H, Yang Z, Huang S, Liu N, et al. Rapid detection of Pseudomonas aeruginosa targeting the toxA gene in intensive care unit patients from Beijing, China. Front Microbiol. 2015;6(6):1100. https://doi.org/10.3389/fmicb .2015 .01100

23. Loveday HP, Wilson JA, Kerr K, Pitchers R, Walker JT, Browne J, et al. Association between healthcare water systems and Pseudomonas aeruginosa infections: a rapid systematic review. $J$ Hosp Infect. 2014;86:7-15. https://doi.org/ 10.1016/j.jhin.2013.09.010

24. Potron A, Poirel L, Nordmann P. Emerging broadspectrum resistance in Pseudomonas aeruginosa and Acinetobacter baumannii: mechanisms and epidemiology. Int $J$ Antimicrob Agents. 2015;45:568-585. https://doi.org/10.1016/j. ijantimicag.2015.03.001

25. Carroll MR, Syrmis MW, Wainwright CE, Greer RM, Mitchell P, Coulter C. Clonal strains of Pseudomonas aeruginusa in paediatric and adult cystic fibrosis units. Eur Respir $J$. 2004;24:101-106. https://doi.org/10.1183/ 09031936.04.00122903

26. Leone I, Chirillo MG, Raso T, Zucca M, Savoia D. Phenotypic and genotypic characterization of Pseudomonas aeruginosa from cystic fibrosis patients. Eur $J$ Clin Microbiol Infect Dis. 2008;27(11):1093-1099. https://doi.org/ 10.1007/s10096-008-0551-1

27. Ruiz L, Domínguez MA, Ruiz N, Viñas M. Relationship between clinical and environmental isolates of Pseudomonas aeruginosa in a hospital setting. Arch Med Res. 200;35(3):251-257. https://doi.org/10.1016/j.arcmed.2004.02.005

28. Trivedi MK, Branton A, Trivedi D, Nayak G, Gangwar M, Snehasis J. Bacterial identification using 16S rDNA gene sequencing and antibiogram analysis on biofield treated Pseudomonas fluorescens. Clin Med Biochem Open Access. 2015;1:101. https://doi.org/10.4172/2471-2663 .1000101

29. Guasp C, Moore ER, Lalucat J, Bennasar A. Utility of internally transcribed $16 \mathrm{~S}-23 \mathrm{~S}$ rDNA spacer regions for the definition of Pseudomonas stutzeri genomovars and other Pseudomonas species. Int J Syst Evol Microbiol. 2000;50(4):1629-1639. https://doi.org/10.1099/o0207713-50-4-1629 
Original Article | Prevailing multidrug $P$. aeruginosa strains

30. Adékambi T, Colson P, Drancourt M. rpoBbased identification of non-pigmented and latepigmenting rapidly growing mycobacteria. J Clin Microbiol. 2003;41(12):5699-708. https://doi .org/10.1128/jcm.41.12.5699-5708.2003

31. Duineveld BM, Kowalchuk GA, Keijzer A, van Elsas JD, van Veen JA. Analysis of bacterial communities in the rhizosphere of chrysanthemum via denaturing gradient gel electrophoresis of PCR-amplified $16 \mathrm{~S}$ rRNA as well as DNA fragments coding for 16S rRNA. Appl Environ Microbiol. 2001;67(1):172-178. https://doi.org/10.1128/AEM.67.1.172-178.2001

32. Didelot X, Bowden R, Wilson DJ, Peto TEA, Crook DW. Transforming clinical microbiology with bacterial genome sequencing. Nat Rev Genet. 2012;13(9):601-612. https://doi.org/10.1038/ $\operatorname{nrg} 3226$
33. Christopher AE, Omoregie R, Igbarumah IO, Onemu S. Microbiology of wound infections among patients of a tertiary hospital in Benin City, Nigeria. J Res Health Sci. 2011;11(2):109113.

34. Dalhatu A, Yunusa U, Ahmad S, Timothy G, Jari S, Musa M. Bacterial agents of abdominal surgical site infections in General Hospital Funtua, Katsina State, North-Western Nigeria. J Dent Med Sci. 2014;13(6):48-52.

35. Masaadeh HA, Jaran AS. Incident of Pseudomonas aeruginosa in postoperative wound infection. Am J Infect Dis. 2009;5(1):1-6. 